\title{
Motivation Strategies and Employee Performance in Non-Profit Organizations
}

\author{
Kalu Ndukw ${ }^{1} \&$ M. M Ofondu ${ }^{1}$ \\ ${ }^{1}$ Department of Management, Abia State University, Ututru, Nigeria \\ Correspondence: Kalu Ndukw, Department of Management, Abia State University, Ututru, Nigeria.
}

Received: November 16, 2018; Accepted: December 3, 2018; Published: December 13, 2018

\begin{abstract}
This study assesses the relationship between motivation techniques and employees performance in the non-profit organizations using five firms in Port Harcourt, Rivers State of Nigeria. Being a survey, structured questionnaire was administered on 130 employees of the firms. Stated hypotheses were tested using simple regression analysis in SPSS version 20.Employee training, work life programmes, monetary incentives and employee recognition were found to have significant and positive impact on employee performance. The study recommends that managers of non-profit organizations should ensure adequate compensation of staff to reduce the rate of employee turnover and they should find out the exact techniques that drive to most.
\end{abstract}

Keywords: motivation, employee performance, non-profit organizations

\section{Introduction}

Best practice business organizations in the world today place higher value on the quality and welfare of their employees. Motivating people to give their best in the work they do has become more crucial than ever, because of stiff competition and economic uncertainties. Besides offering customer-centric products (goods and services), establishing and maintaining stable and reliable workforce through attractive motivational strategies, have been proven by scholars as a key driver of enviable competitive advantage by both profit-oriented and not-for-profit organizations (Mullins, 2005).The main factor that can set apart an organization in turbulent times and difficult environment be it in manufacturing and service organizations is its people, therefore establishing and maintaining a stable workforce is a major concern for human resource department in most organizations. Employees of an organization will be motivated, if they associate certain incentives with an activity of work. The success of every organization whether private or public, small or large, profit or non-profit depends on the optimal functionality of its managerial potentials, availability of human and natural resources and efficient utilization of the resources (Higgins, 1994).

Motivation in the work context is defined as an individual's degree of willingness to exert high level of effort to reach organizational goals (Higgins, 1994). Decenzo (2001) defines it as the result of the interaction between an individual and the situation. Naturally, organizations seek out individuals who are motivated to perform effectively in the workplace. In addition, they tend to employ people who have the ability to motivate others with whom they work. Also, most organizations have realized that the performance of their employees play a vital role in determining the success of the organization (Ajila and Awonusi, 2004). As such it is important for employers and managers alike to know the mechanism or methods which will enhance workers motivation. Thus motivation strategies are the different methods, tools, techniques, systems, or process that organizations put in place to encourage employees to put in their best on the job, hence, resulting to higher productivity and better organizational performance.

Oluseyi and Ayo (2009) maintain that keeping employees motivated and engaged is the key to every organization's success. Motivation is a management tool recognized in the past by many authors and emphasized rapidly through time, as the management theory evolves. One of the clearest and simplest definitions of motivation in management is "getting correct things done through people willingly (Chopra, 2002). Motivation is a tool that non-profit organizations can utilize effectively to achieve stated goals, including improved employee performance. Given their non-profit nature and increasing interest on financially-oriented motivational packages by employees in Nigeria, in view of the prevailing economic circumstances, there is urgent need to identify those motivational techniques that drive positive employee performance in the non-profit organizations. 


\subsection{Statement of the Problem}

Researchers have studied employee motivation at length; the biggest misconception has been that good wages were the primary motivational factor among employees regardless of the industry by which they are employed. This generalization or supposed knowledge has misdirected frontline supervisors and managers for years. Effective motivation of employees in non-profit organization has become one of the most challenging in the light of organizational trends to downsize, and in relation to the demands associated with managing a diverse workforce Not much attention has been paid to motivate employees in non-profit organizations. This may be due to the small size of majority of the organizations. Various authors have suggested that goals and objectives for voluntary organizations should often best be obtained by the use of intrinsically motivated employees as well as employees who sympathize with goals and objectives of the organization but in most developing countries as Nigeria, where a large percentage of her populace are living below the standard of living, it becomes a difficult task to ascertain committed employees who could willingly work to achieve the goals.

\subsection{Objectives of the Study}

The key objective of the study is to evaluate the various motivational strategies adopted by non-profit organizations and the impact of the strategies on employee performance. The specific objectives are:

i. To evaluate the effect of monetary incentives on the performance of employees of non-profit organizations.

ii. To measure the nature of the relationship between employee training and performance of employees of non-profit organizations.

iii. To measure the extent of relationship between quality of work life program and performance of employees of non-profit organizations.

iv. To evaluate the effect of employee recognition on the performance of employees of non-profit organizations.

\subsection{Research Hypotheses}

The following hypotheses were tested in this study:

$\mathrm{H}_{01}$ : Monetary incentives have no positive and significant effect on the performance of employees of non-profit organizations.

$\mathrm{H}_{02}$ : There is no significant and positive relationship between employee training and performance of employees of non-profit organizations.

$\mathrm{H}_{03}$ : Quality of working life environment does not influence the performance of employees of non-profit organizations.

$\mathrm{H}_{04}$ : There is no significant and positive relationship between employee recognition and the performance of employees of non-profit organizations.

\subsection{Scope of the Study}

This research is focused on the assessment of the effect of motivational strategies in non-profit organizations with particular reference to three (3) non-profit making organizations in Port Harcourt, Rivers State. All the staff of the organizations under study shall form the population for the study.

\section{Review of Related Literature}

\subsection{Conceptual Framework}

Motivation has remained a difficult term to define as it is almost impossible to find two exact same definitions of the term. This proves the complexity of the term itself, and showing the subjectivity of many authors. Motivation is a fallout of the Latin word "Movere" meaning to move. Some authors cite different roots of the word and translate it as "to stimulate" (Pakdel, 2013). Barnet (2002) offers a broader definition thus, "the forces acting on or within a person that cause the arousal, direction, and persistence of goal-directed voluntary effort". That is, motivation theory is concerned with the process that explains why and how human behavior is activated.

\subsection{Motivational Techniques/Strategies}

Uzonna (2013) identified motivational techniques to include: Team-building, training, enhanced communication, targets, rewards and incentives, job enrichment, encouraging participation, quality of working life programs, checking system for equity, money and recognizing individual differences. However, due to the nature of this study, the following techniques are briefly discussed: 
Training: People can be taught to become more motivated by showing them how to deconstruct tasks and challenges, and how to feel less intimidated by their job roles. Demonstrating to them how to cope in the workplace can lead directly to improved motivation (Daniel, 2001).

Quality of Working Life Programs: These programs as described by Koontz and Weihrich (1990) and Bateman and Snell (2004) create a workplace that enhances employees' well being and satisfaction. The general goal is to satisfy a full range of employees needs: Adequate and fair compensations, safe and healthy environments, jobs that develop human capacities, chance for personal growth and security, social environment that fosters personal identity, freedom from prejudice, sense of community, and upward mobility, constitutionalism, or rights of personal privacy, dissent and due process, work role that minimizes infringement on personal leisure and family needs and socially responsible organizational actions.

Money: For some categories of employees, money will always be of utmost importance, while for others it is not. An organization is expected to know those employee classified as economic-conscious and who will prefer monetary incentives to mere recognition and awards. The way to ensure that money has meaning, as a reward for accomplishment and as a way of giving people pleasure from accomplishment, is to base compensation as much as possible on performance (koontz \& Weihrich, 1990).

Recognizing Individual Differences: Employees have different needs. It is important not to treat them all alike. Important note should be made to understand what is important to each employee. This allows for individualizing goals, levels of involvement, and rewards to align with individual needs (Robbins, 1998).

\subsection{Classification of Motivation}

Scholars have explained that motivation can be divided into two main groups: physical and mental or psychical motivation. The physical motivation represents the lowest levels of human needs, the physical ones. It represents the motivation to fulfill basic natural needs like need for air, food, water or space (McClelland, 1987). Psychical motivation can be explained as acting of a human because it thinks it is a right thing to do and agrees with acceptable values. Again, social motivation as a part of psychological motivation pertains only to human and can be observed only in that way. Social motivation is on a higher level of motivation goals because accomplishing these goals definitely comes after the primary, physical needs. The need to belong, to be accepted, and to be valued by ones relevant social groups is considered to be one of the most basic human needs (Dunning, 2011, p. 59). People are motivated to become a good and valued member of their social groups and to be viewed by themselves and others as such (Dunning, 2011). Others are:

Extrinsic motivation which is related to 'tangible' rewards such as salary and fringe benefits, security, promotion, contract of service, the work environment and conditions of work. Such tangible rewards are often determined at the organizational level and may be largely outside the control of individual managers (Mullins, 2005).

Intrinsic motivation which is related to 'psychological' rewards such as opportunity to use on "s ability, a sense of challenge and achievement, receiving appreciation, positive recognition, and being treated in a caring and considerate manner. The psychological rewards are those that can usually be determined by the actions and behaviour of individual managers (Mullins, 2005) Given the complex and variable nature of needs and expectations, the following is a simple and useful three fold classification for reviewing the motivation to work developed by Mullins (2005).

Economic Rewards: Such as pay, fringe benefits, pension rights, material goods and security.

Intrinsic Satisfaction: Derived from the nature of the work itself, interest in the job and personal growth and development. This is a personal orientation to work.

Social Relationships: Such as friendships group workings, and the desire for affiliation, status and dependency. This is a relational orientation to work and be concerned about other people.

\subsection{Theoretical Framework: Herzberg Two Factor Theory}

This study is based on the Herzberg (1959) two factor theory which states that certain factors cause job satisfaction, and separate set of factors cause dissatisfaction. The study therefore informed the study if non-profit organization employees are influenced by the two factors of motivation and hygiene to volunteer and further, if the factors influence their job satisfaction and performance. According to Herzberg (1959) the hygiene factors (work condition, salary, supervision, company policy), can de-motivate or cause dissatisfaction if they are not present, but do not often create satisfaction when they are not present. However, motivation factors (achievements, recognition, growth, responsibility, job satisfaction and the work itself) do motivate or create satisfaction and are really the cause of dissatisfaction. 
Herzberg's theory also enabled the study understand whether the motivation and the hygiene factors provide long term or short term influence to non-profit making organization in terms of their commitment to volunteer, attitude, their job satisfaction, dissatisfaction and productivity. To him, the motivators were elements that enhanced a person's job. These motivators/satisfiers were associated with long term positive effects of job performance while the hygiene factors (dissatisfiers) consistently produced only short term changes in job attitude and performance, which quickly would go back to its previous level. It is surmised that the motivators described a person's relationship to the environment in which he or she performed her job. The theory further enabled the study understand why a continuous management process is significant for job satisfaction. The process gives emphasis on assigning jobs to the employees of non-profit organization which will enable them use their full ability and provide them enough challenge. Additionally, an employee who demonstrates an increasing high level of ability should be giving corresponding increasing levels of responsibility. If this is not achieved where individuals cannot use their skills to full then, they will experience difficulty with motivation.

Considering the fact that volunteers provide human resources, the Herzberg theory (1959) enabled the study understand if creating conditions by the voluntary organizations that make employees fulfilled in their work place is significant or not. It is assumed that these groups of social workers are motivated by personal factors rather than organizational factors. The theory surmises that organizations require to motivate their employees by paying attention to hygiene factors and by enabling satisfiers. Therefore, this can be by motivating and empowering the employees through delegating responsibilities to them, involving them in decision making, acknowledging and recognizing their contributions among others. Motivating non-profit organization employee is termed as an important task to all managers considering that a motivated work force improves production resulting in good performance.

\subsection{Empirical Review}

It is pertinent to observe that many studies have been carried out to assess the motivational strategies of non-profit organizations and in related subjects in general. Klein, Sondag \& Dronet (1994). Mikee (2003); Smith (2005) in their study titled "relevance of motivational strategies to the performance of non-profit organization using 86 organizations in their study found out that recognition is important to most volunteers in most non-profit organizations; their work also revealed that goal oriented assignment help volunteers know what is expected of them and how their effort contribute to the goal, bringing a sense of accomplishment to volunteers when the goal is met.

Saavedra and Kwun (2000) concluded a research by investigating if the job characteristics theory related to affect non-profit organizations exist which is a consequence of an affective job experience. Their research was conducted quantitatively and investigated positively and negative relations. The authors found that the characteristics that are related to the motivating potentials of a job are also related to the affective at work in non-profit organizations. Fischer, 2003; Kreitner \& Kinicki, 2007; Wright, Larsen and Higgs, (1995) in their study sought to identify the motivational strategies in existence in the voluntary organization and their effect on voluntary performance. The study found out that both motivational and hygienic factors were significant when it comes to volunteers performance and satisfaction.

Richard (2014) carried out a study on "The Effect of Motivation on Employees Performance: Empirical Evidence from the Brong Ahafo Education Directorate". The general objective of the study was to determine the Effect of Motivation on Employees; to identify factors that motivate employees; to determine the employees' performance and to assess the effect of motivation on the employees' performance in Asunafo North Municipal Education Directorate. Mixed methodology, that is questionnaires and interviews were used to gather data and analysis was done using Statistical Package for Social Sciences (SPSS), and content analysis for qualitative aspect. The study revealed that promotion and opportunity for advancement are the major motivation factors and the study has also revealed that motivation level is low in the area of wages and salaries. It was therefore recommended that Ghana Education Service (management) should consider as a matter of urgency, the need to make upward adjustment in wages and salaries which will go a long way to reduce the high incidence of labour turnover.

Ekpudu and Ojeifo (2014) studied on, "financial incentives and rewards on employee motivation in the Nigerian electricity distribution company". The study used likert scale form questionnaire to gather data from purposive selected employees of the company. On one hand, respondents were asked to rank six financial and non-financial incentives and rewards in order of importance. The result revealed that financial incentives and rewards were more important and motivating to the respondents. On the other hand, Chi-Square cross-tabulation on the hypotheses revealed that financial incentives and rewards influence employee attitude, job satisfaction and productivity irrespective of gender and cadre in the organization. The study concluded that financial incentives and rewards 
motivate employee to have positive attitude at work, lead to job satisfaction, improve productivity, and recommended that employers should concentrate more on it to ensure employee positive attitude, job satisfaction, improved productivity and performance.

Saleem (2011) carried a study on the "impact of financial incentives and rewards on employee's commitment". A total of 100 employees from the Private Sector Banks, Public Sector Banks, Islamic Banks and Microfinance Banks at Bahawalpur that includes 71 male and 29 female. Random sampling was used as a sampling design and questionnaire in Likert form was used to gather data from the participants. Linear regression was used to investigate the relationship between financial incentives and employee's commitment. Results however revealed positive and significant association between financial incentives and employee commitment and increase in financial incentives such as promotion and bonuses enhanced employee commitment which increases the employee's performance and reduces turnover and employees can only be loyal when their wants and desires are satisfied.

Elnaga and Imran (2013) studied "The Effect of Training on Employee Performance". This conceptual paper aimed at studying the effect of training on employee performance and to provide suggestion as to how firm can improve its employee performance through effective training programs. The research approach adopted for the study conforms to qualitative research, as it reviews the literature and multiple case studies on the importance of training in enhancing the performance of the workforce. Further the paper goes on to analyze and understand the theoretical framework and models related to employee development through training and development programs, and its effect on employee performance and on the basis of the review of the current evidence of such a relationship, offers suggestions for the top management in form of a checklist, appropriate for all businesses, to assess the employee performance and to find out the true cause(s) of the performance problem so the problem could be solved in time through desired training program.

Muindi and K'Obonyo (2015) investigated on the "Quality of work life, personality, job satisfaction, competence, and job performance: a critical review of literature". This study looked at selected employee related factors, namely: employee personality, job satisfaction, and competence. QWL was included because organizations are known to adopt a strategy for improving employees' Quality of Work Life (QWL) with the aim of satisfying both the organizational objectives and the needs of the employee. On the other hand, successful organizations consider job satisfaction to be important for work performance. However, job satisfaction alone cannot lead to performance. Having the right competences is important for performance. This review therefore sought to investigate the employee related factors that influenced the relationship between quality of work life and employee's performance. The study found out that quality of work life programs should be associated with such affective outcomes such as increased job satisfaction, improved employee performance to the extent that they enhance employee participation, and involvement and responsibility.

Abdullah and Wan (2013) carried out a study on "Relationships of Non-Monetary Incentives, Job Satisfaction and Employee Job Performance". The objective of the paper is to present the theoretical and empirical evidences conceptually regarding the relationships between non-monetary incentives and job satisfaction in influencing job performance. The paper discusses direct linear relationship between non-monetray incentives and job satisfaction as independent variables and job performance as dependent variable. The study used theoretical and empirical studies to support the hypotheses that non-monetary incentives and job satisfaction influence job performance. The study proposed that non-monetary incentives and job satisfaction significantly and positively influence job performance particularly when a variety of non-monetary incentives are used among satisfied employees in an organization.

\subsection{The GAP}

Most studies on motivational strategies were carried out in profit oriented organizations, the few that are on non-profit organizations were mostly done outside Nigeria. This study was carried out in non-profit organizations in Rivers State, thereby closing the gap on empirical studies in this area within the State.

\section{Research Methodology}

The researcher adopted the survey research. Structured questionnaire was the major instrument used in eliciting relevant primary data from the respondents. The questionnaire was sub-divided into two sections. Section A covered the demographic characteristics of respondents, while section B was used to elicit important questions that assisted the researcher to harmonize the objectives of the study and the hypothesis. The questionnaire was designed in five point Likert and rating scale.Since the target population of this study was the employees of non-profit organizations in Port-Harcourt, Rivers state, the researcher restricted the frame to five non-profit 
organizations and their staff strength as contained in the internal records as at December 2017 showed a total of 130 employees. The Taro Yeman formula was used to ascertain the appropriate sample size of 98 for the study.

The simple random sampling technique was employed.

To ensure validity of the instrument, the instrument was vetted and authenticated by the researcher's supervisor, management practitioners and other research experts. In testing the reliability of the instrument, the researcher issued ten (10) copies of the questionnaire to ten randomly selected employees of Noble Talent International, a non-profit organization in Port-Harcourt, though not used in the main work. After two weeks, copies were re-issued and collected. Responses in the two sets were correlated and a co-efficient value of $78 \%$ was realized (74\% $+82 \%=156 / 2=78 \%$ ). Thus, the researcher found the instrument reliable based on the opinions of scholars. Collected data were analyzed using tables, charts and simple percentages. Stated hypotheses would be tested using simple regression analysis at 0.05 level of significance in SPSS version 20. Thus, the model specification is given by:

$\mathrm{Y}=\mathrm{F}\left(\mathrm{X}_{1}, \mathrm{X}_{2}, \mathrm{X}_{3}, \mathrm{X}_{4}\right)$.

Where:

$\mathrm{Y}=$ Independent variable (Employee performance) represented on table 4.

$\mathrm{X}_{1}=$ First dependent variable (financial incentives) represented on table 6.

$\mathrm{X}_{2}=$ Second dependent variable (training) represented on table 7.

$\mathrm{X}_{3}=$ Third dependent variable (quality of working life programs)represented on table 8 .

$\mathrm{X}_{4}=$ Fourth dependent variable (Recognition) represented on table 9

The composition, direction and relative strength of each of the four independent variables on the single dependent variable (FI) were determined.

Decision Rules

In order to validate (accept) or nullify (reject) any stated hypothesis tested with the simple regression, major attention was paid to the P- values of the tested constructs. Therefore, we rejected the null hypotheses where the SPSS p-values were less than alpha (0.05) and the alternative hypotheses accepted.

\section{Results}

Table 4.1 Questionnaire distribution and returns rate

\begin{tabular}{lllll}
\hline Firm & $\begin{array}{l}\text { Number of Copies } \\
\text { Distributed }\end{array}$ & $\begin{array}{l}\text { Number } \\
\text { Retrieved Copies }\end{array}$ & $\begin{array}{l}\text { Number of Valid/Used } \\
\text { Copies }\end{array}$ & $\begin{array}{l}\text { Percentage of } \\
\text { Valid/Used Copies }\end{array}$ \\
\hline HRRDO & 17 & 15 & 14 & 17 \\
JA & 13 & 11 & 11 & 14 \\
ISSJGG & 23 & 21 & 19 & 23 \\
GCDF & 26 & 24 & 21 & 26 \\
AII & 19 & 17 & 16 & 20 \\
\hline Total & $\mathbf{9 8}$ & $\mathbf{8 8}$ & $\mathbf{8 1}$ & $\mathbf{1 0 0}$ \\
\hline
\end{tabular}

Source: Field Survey, 2017

Table 4.1 shows that out of the a total of 98 copies of the questionnaire distributed to respondents, 88 copies were retrieved. This was $90 \%$ of the sample size. However, out of this number, only 81 copies were found valid and useful for further analyses. This was $83 \%$ of the sample size and $92 \%$ of the total number of copies retrieved. That is, $14(17 \%)$ copies, $11(14 \%)$ copies, $19(23 \%)$ copies, $21(26 \%)$ copies and $16(20 \%)$ copies were retrieved from Human Right and Rural Development Organization of Nigeria, Junior Achievement, International Society for Social Justice and Good Governance, Guidance Community Development Foundation, Port-Harcourt and Action Aid International, River State, respectively. Further analyses were based on the 81 copies retrieved and found valid. 
Table 4.2 Demographics of respondents

\begin{tabular}{lll}
\hline Categories & Frequency & Percentage \\
\hline Gender: & 46 & 57 \\
Male & 35 & 43 \\
\hline Female & 35 & 43 \\
\hline Single & 32 & 40 \\
Married & 14 & 17 \\
Other & & \\
\hline Age Bracket & 10 & 12 \\
Less than 25 & 18 & 22 \\
$25-30$ & 21 & 27 \\
$31-35$ & 14 & 17 \\
$36-40$ & 10 & 12 \\
$41-45$ & 08 & 10 \\
46 years and above & & \\
\hline Educational Qualification: & 14 & 17 \\
O'Level & 22 & 27 \\
ND & 38 & 47 \\
HND/B.Sc. & 07 & 09 \\
Master and Above & & \\
\hline Length of Service & 20 & 25 \\
Below 1 year & 18 & 22 \\
1-3 years & 28 & 35 \\
$4-6$ years & 10 & 12 \\
$7-9$ years & 05 & 06 \\
Above 9 years & & \\
\hline & & \\
\hline & & \\
\hline
\end{tabular}

Source: Field Survey, 2017

Table 4.2 shows that there were $46(57 \%)$ male respondents and 35 (43\%) female respondents. Also, 35 (43\%) respondents, $32(40 \%)$ respondents and $14(17 \%)$ respondents. In terms of their age brackets, the table shows that $10(12 \%)$ respondents, $18(22 \%)$ respondents, $21(27 \%)$ respondents, $14(17 \%)$ respondents, $10(12 \%)$ respondents and $8(10 \%)$ respondents were within the ages of: less than 25 years, $25-30,31-35,36-40,41-45$ and 46 years and above, respectively.

Moreover, data presented on the table shows that 14 (17\%) respondents, $22(27 \%)$ respondents, $38(47 \%)$ respondents and $7(09 \%)$ respondents had O'Level, ND, HND/B.Sc. and Masters and above, respectively. On the other hand, $20(25 \%)$ respondents, $18(22 \%)$ respondents, $28(35 \%)$ respondents $10(12 \%)$ respondents and 05 (06\%) respondents had worked in their various firms for periods of less than one year, 1 - 3 years, 4 - 6 years, 7 - 9 years and above 9 years, respectively.

Table 4.3 Responses on the relationship between motivation and employee performance

\begin{tabular}{llllllll}
\hline S/N & Statement & SA & A & N & D & SD & Total \\
\hline 1. & Adequate motivation has influence on my job satisfaction. & 38 & 20 & 07 & 08 & 08 & 81 \\
2. & $\begin{array}{l}\text { When employees are properly motivated, organizational goals are } \\
\text { achieved. }\end{array}$ & 31 & 10 & 09 & 06 & 81 \\
3. & $\begin{array}{l}\text { Organizations that have good motivational packages achieve better } \\
\text { results than those that have poor motivational packages. }\end{array}$ & 28 & 06 & 04 & 03 & 81 \\
When the right motivational strategies are implemented by & 42 & 22 & 10 & 05 & 02 & 81 \\
& $\begin{array}{l}\text { non-profit organizations, employee performance remains high. } \\
\text { Total }\end{array}$ & $\mathbf{1 4 5}$ & $\mathbf{1 0 1}$ & $\mathbf{3 3}$ & $\mathbf{2 6}$ & $\mathbf{1 9}$ & $\mathbf{3 2 4}$ \\
$\begin{array}{l}\text { Average Total } \\
\text { Percentage }\end{array}$ & $\mathbf{3 6}$ & $\mathbf{2 5}$ & $\mathbf{0 8}$ & $\mathbf{0 7}$ & $\mathbf{0 5}$ & $\mathbf{8 1}$ \\
\hline & $\mathbf{4 4}$ & $\mathbf{3 1}$ & $\mathbf{1 0}$ & $\mathbf{0 9}$ & $\mathbf{0 6}$ & $\mathbf{1 0 0}$ \\
\hline
\end{tabular}

Source: Field Survey, 2017 
Analysis on table 4.3 shows that on the average, $36(44 \%)$ respondents, $25(31 \%)$ respondents, $8(10 \%)$ respondents, $7(9 \%)$ and $5(6 \%)$ respondents strongly agreed, agreed, were yet to decide, disagreed and strongly disagreed, respectively, on the relationship between motivation and employee performance. This means that there $61(75 \%)$ positive responses and $12(15 \%)$ negative responses on the relationship between the two variables; while $8(10 \%)$ of the responses were indifferent.

Table 4.4 Responses on the relationship between financial incentives and employee performance

\begin{tabular}{|c|c|c|c|c|c|c|c|}
\hline $\mathbf{S} / \mathbf{N}$ & Statement & SA & A & $\mathbf{N}$ & D & SD & Total \\
\hline 1. & $\begin{array}{l}\text { When employees receive financial rewards commensurate with their } \\
\text { input in the organization, they perform better. }\end{array}$ & 50 & 19 & 05 & 05 & 02 & 81 \\
\hline 2. & When employees are paid at the right time, they tend to work harder. & 35 & 33 & 06 & 04 & 03 & 81 \\
\hline 3. & $\begin{array}{l}\text { Because I am well paid by my firm, I initiate new ideas for better } \\
\text { performance. }\end{array}$ & 31 & 25 & 11 & 08 & 06 & 81 \\
\hline \multirow[t]{4}{*}{4.} & $\begin{array}{l}\text { I have no intention of leaving the firm because I am satisfied with my } \\
\text { pay. }\end{array}$ & 48 & 15 & 04 & 08 & 06 & 81 \\
\hline & Total & 164 & 92 & 26 & 25 & 17 & 324 \\
\hline & Average Total & 41 & 23 & 07 & 06 & 04 & 81 \\
\hline & Percentage & 51 & 28 & 09 & 07 & 05 & 100 \\
\hline
\end{tabular}

Source: Field Survey, 2017

Analysis on table 4.4 shows that on the average, $41(51 \%)$ respondents, $23(28 \%)$ respondents, 7 (9\%) respondents, $6(7 \%)$ and $4(5 \%)$ respondents strongly agreed, agreed, were yet to decide, disagreed and strongly disagreed, respectively, on the relationship between financial incentives and employee performance. This means that there are $64(79 \%)$ positive responses and $10(12 \%)$ negative responses on the relationship between the two variables; while $7(9 \%)$ of the responses were indifferent.

Table 4.5 Responses on the relationship between training and employee performance

\begin{tabular}{|c|c|c|c|c|c|c|c|}
\hline $\mathbf{S} / \mathbf{N}$ & Statement & SA & A & $\mathbf{N}$ & D & SD & Total \\
\hline 1. & Adequate training of employees results in improved performance. & 42 & 20 & 12 & 04 & 03 & 81 \\
\hline 2. & Training improved the skills of the employees at work. & 48 & 08 & 15 & 05 & 05 & 81 \\
\hline 3. & $\begin{array}{l}\text { Effective training programme enables employees to know ad work } \\
\text { towards the organizational objectives. }\end{array}$ & 38 & 20 & 07 & 09 & 07 & 81 \\
\hline 4. & Training enables employees to adapt to changes easily. & 33 & 35 & 05 & 06 & 02 & 81 \\
\hline & Total & 161 & 83139 & 24 & 17 & 17 & 324 \\
\hline & Average Total & 40 & 21 & 10 & 06 & 04 & 81 \\
\hline & Percentage & 51 & 28 & 09 & 07 & 05 & 100 \\
\hline
\end{tabular}

Source: Field Survey, 2017

Analysis on table 4.5 shows that on the average, 40 (51\%) respondents, 21 (28\%) respondents, $10(9 \%)$ respondents, $6(7 \%)$ and $4(5 \%)$ respondents strongly agreed, agreed, were yet to decide, disagreed and strongly disagreed, respectively, on the relationship between financial incentives and employee performance. This means that there are $61(79 \%)$ positive responses and $10(12 \%)$ negative responses on the relationship between the two variables; while $10(9 \%)$ of the responses were indifferent.

Table 4.6 Responses on the relationship between work life quality and employee performance

\begin{tabular}{llllllll}
\hline S/N & Statement & SA & A & N & D & SD & Total \\
\hline 1. & $\begin{array}{l}\text { A peaceful work environment enables employees to perform their } \\
\text { duties effectively. }\end{array}$ & 19 & 06 & 06 & 04 & 81 \\
2. & & & & & & \\
3.tractive welfare packages encourage hard work among employees. & 42 & 22 & 10 & 05 & 02 & 81 \\
& $\begin{array}{l}\text { The leadership style of the management influences employee } \\
\text { performance. }\end{array}$ & 15 & 05 & 07 & 06 & 81
\end{tabular}


4. I recommend my firm to others.

\begin{tabular}{llllll}
40 & 26 & 08 & 03 & 04 & 81 \\
\hline $\mathbf{1 7 6}$ & $\mathbf{8 2}$ & $\mathbf{2 9}$ & $\mathbf{2 1}$ & $\mathbf{1 6}$ & $\mathbf{3 2 4}$ \\
$\mathbf{4 4}$ & $\mathbf{2 1}$ & $\mathbf{0 7}$ & $\mathbf{0 5}$ & $\mathbf{0 4}$ & $\mathbf{8 1}$ \\
$\mathbf{5 4}$ & $\mathbf{2 7}$ & $\mathbf{0 9}$ & $\mathbf{0 6}$ & $\mathbf{0 5}$ & $\mathbf{1 0 0}$
\end{tabular}

Total

Average Total

$\begin{array}{llllll}54 & 27 & 09 & 06 & 05 & 100\end{array}$

Source: Field Survey, 2017

Analysis on table 4.6 shows that on the average, 44 (54\%) respondents, 21 (27\%) respondents, 7 (9\%) respondents, $5(6 \%)$ and $4(5 \%)$ respondents strongly agreed, agreed, were yet to decide, disagreed and strongly disagreed, respectively, on the relationship between work life quality and employee performance. This means that there are $65(81 \%)$ positive responses and $9(11 \%)$ negative responses on the relationship between the two variables; while $7(9 \%)$ of the respondents were indifferent.

Table 4.7 Responses on the relationship between recognition and employee performance

\begin{tabular}{|c|c|c|c|c|c|c|c|}
\hline $\mathbf{S} / \mathbf{N}$ & Statement & SA & A & $\mathbf{N}$ & D & SD & Total \\
\hline 1. & $\begin{array}{l}\text { At one point or the other, my opinion had been sought on issues } \\
\text { concerning the organization ad her policies. }\end{array}$ & 50 & 18 & 05 & 04 & 04 & 81 \\
\hline 2. & I feel happy when my efforts are being recognized. & 37 & 21 & 16 & 05 & 02 & 81 \\
\hline 3. & I put in more effort when I am recognized. & 41 & 22 & 09 & 05 & 04 & 81 \\
\hline 4. & $\begin{array}{l}\text { I see myself as part and passel of the organization because I am } \\
\text { always recognized. }\end{array}$ & 40 & 23 & 10 & 06 & 02 & 81 \\
\hline & Total & 168 & 84 & 40 & 20 & 12 & 324 \\
\hline & Average Total & 42 & 21 & 10 & 05 & 03 & 81 \\
\hline & Percentage & 52 & 26 & 12 & 06 & 04 & 100 \\
\hline
\end{tabular}

Source: Field Survey, 2017

Analysis on table 4.7 shows that on the average, $42(52 \%)$ respondents, $21(26 \%)$ respondents, 10 (12\%) respondents, $5(6 \%)$ and $3(4 \%)$ respondents strongly agreed, agreed, were yet to decide, disagreed and strongly disagreed, respectively, on the relationship between recognition and employee performance. This means that there are $63(78 \%)$ positive responses and $8(10 \%)$ negative responses on the relationship between the two variables; while $10(12 \%)$ of the respondents were indifferent.

\subsection{Test of Hypothesis One}

$\mathrm{H}_{1}$ : Monetary incentives have positive and significant effect on the performance of employees of non-profit organizations.

To test this hypothesis, data on tables 4.3 and 4.4 were used. The SPSS output is presented as appendix two:

Model Summary ${ }^{b}$

\begin{tabular}{llllll}
\hline Model & $\mathrm{R}$ & R Square & Adjusted R Square & Std. Error of the Estimate & Durbin-Watson \\
1 & $.904^{\mathrm{a}}$ & .818 & .816 & .53620 & 1.746 \\
\hline
\end{tabular}

a. Predictors: (Constant), financial incentives

b. Dependent Variable: PERFORMANCE OF EMPLOYEE

\begin{tabular}{|c|c|c|c|c|c|c|}
\hline Model & & Sum of Squares & df & Mean Square & $\mathrm{F}$ & Sig. \\
\hline \multirow{3}{*}{1} & Regression & 101.978 & 1 & 101.978 & 354.688 & $.000^{\mathrm{b}}$ \\
\hline & Residual & 22.714 & 79 & .288 & & \\
\hline & Total & 124.691 & 80 & & & \\
\hline
\end{tabular}

a. Dependent Variable: PERFORMANCE OF EMPLOYEE

b. Predictors: (Constant), financial incentives

Interpretation: The $\mathrm{R}^{2}$ value of 0.904 shows a significance positive relationship between employee performance and financial incentives. The Adjusted $\mathrm{R}$ value indicates that $81.6 \%$ variations on employee performance in the non-profit organizations are accounted for by financial incentives. Also, the value off (354.69) and p value (0.000) which are greater 
than $\mathrm{f}$ critical value at $0.05 \%(6.39)$ and less than alpha $(0.05)$ respectively are positive signs of relationship.Also the DW tests show that the residuals from the linear regression are independent, while there is no first order linear autocorrelation in the simple regression data. Since the values fall between $1.611<\mathrm{d}<1.662$ and they tend to be closer to 4 as against 0 .

Decision: Since F calculated (354.69) is greater than F critical (6.39) and the p value (0.000) is less than alpha (0.05), we therefore reject the Null hypothesis and accept the alternative hypothesis which states that there is positive relationship between employee performance and financial incentives.

\subsection{Test of Hypothesis Two}

$\mathrm{H}_{1}$ :There is significant and positive relationship between employee training and performance of employees of non-profit organizations.

To test this hypothesis, data on tables 4.3 and 4.5 were used. The SPSS output is presented as appendix three:

Model Summary ${ }^{\mathrm{b}}$

\begin{tabular}{llllll}
\hline Model & $\mathrm{R}$ & $\mathrm{R}$ Square & Adjusted R Square & Std. Error of the Estimate & Durbin-Watson \\
1 & $.910^{\mathrm{a}}$ & .828 & .826 & .52063 & 1.767 \\
\hline
\end{tabular}

a. Predictors: (Constant), EMPLOYEE TRAINNING

b. Dependent Variable: PERFORMANCE OF EMPLOYEE

\begin{tabular}{lllllll}
\multicolumn{1}{l}{ ANOVA $^{\mathbf{a}}$} & & & & \\
\hline Model & & Sum of Squares & Df & Mean Square & F & Sig. \\
\hline \multirow{2}{*}{1} & Regression & 103.278 & 1 & 103.278 & 381.018 & $.000^{\mathrm{b}}$ \\
& Residual & 21.414 & 79 & .271 & & \\
& Total & 124.691 & 80 & & & \\
\hline
\end{tabular}

a. Dependent Variable: PERFORMANCE OF EMPLOYEE

b. Predictors: (Constant), EMPLOYEE TRAINNING

Interpretation: The $\mathrm{R}^{2}$ value of 0.910 shows a significance positive relationship between employee performance and employee training. The Adjusted $\mathrm{R}$ value indicates that $82.8 \%$ variations on employee performance in the non-profit organizations are accounted for by employee training. Also, the value ofF (381.02) and p value (0.000) which are greater than $\mathrm{f}$ critical value at $0.05 \%(6.39)$ and less than alpha $(0.05)$ respectively are positive signs of relationship. Also the DW tests show that the residuals from the linear regression are independent, while there is no first order linear autocorrelation in the simple regression data. Since the values fall between $1.611<\mathrm{d}<1.662$ and they tend to be closer to 4 as against 0 .

Decision: Since F calculated (381.02) is greater than F critical (6.39) and the p value (0.000) is less than alpha $(0.05)$, we therefore reject the Null hypothesis and accept the alternative hypothesis which states that there is positive relationship between employee training and performance of employees of non-profit organizations.

\subsection{Test of Hypothesis Three}

$\mathrm{H}_{1}$ : Quality of working life program does not influence the performance of employees of non-profit organizations.

To test this hypothesis, data on tables 4.3 and 4.6 were used. The SPSS output is presented as appendix three:

Model Summary

\begin{tabular}{llllll}
\hline Model & $\mathrm{R}$ & R Square & Adjusted R Square & $\begin{array}{c}\text { Std. Error of the } \\
\text { Estimate }\end{array}$ & Durbin-Watson \\
\hline 1 & $.947^{\mathrm{a}}$ & .897 & .896 & .40305 & .619 \\
\hline a. Predictors: (Constant), worklife quality & & & \\
b. Dependent Variable: PERFORMANCE OF EMPLOYEE & & \\
\hline
\end{tabular}

\begin{tabular}{lllllll}
\multicolumn{1}{l}{ ANOVA $^{\mathrm{a}}$} \\
\hline Model & & Sum of Squares & $\mathrm{df}$ & Mean Square & F & Sig. \\
\hline \multirow{4}{*}{1} & Regression & 111.858 & 1 & 111.858 & 688.572 & $.000^{\mathrm{b}}$ \\
& Residual & 12.833 & 79 & .162 & & \\
& Total & 124.691 & 80 & & & \\
\hline
\end{tabular}

a. Dependent Variable: PERFORMANCE OF EMPLOYEE

b. Predictors: (Constant), worklife quality 
Interpretation: The $\mathrm{R}^{2}$ value of 0.947 shows a significance positive relationship between employee performance and quality of working life programme. The Adjusted $\mathrm{R}$ value indicates that $89.7 \%$ variations on employee performance in the non-profit organizations are accounted for by quality of working life programme. Also, the value ofF (688.57) and $p$ value $(0.000)$ which are greater than $\mathrm{f}$ critical value at $0.05 \%(6.39)$ and less than alpha $(0.05)$ respectively are positive signs of relationship. Also the DW tests show that the residuals from the linear regression are independent, while there is no first order linear autocorrelation in the simple regression data. Since the values fall between $1.611<\mathrm{d}<1.662$ and they tend to be closer to 4 as against 0 .

Decision: Since F calculated (688.57) is greater than F critical (6.39) and the p value (0.000) is less than alpha (0.05), we therefore reject the Null hypothesis and accept the alternative hypothesis which states that there is positive relationship between employee performance and quality of working life programme.

\subsection{Test of Hypothesis Four}

$\mathrm{H}_{1}$ : There is no significant and positive relationship between employee recognition and the performance of employees of non-profit organizations.

To test this hypothesis, data on tables 4.3 and 4.7 were used. The SPSS output is presented as appendix three:

Model Summary

\begin{tabular}{lllllc}
\hline Model & R & R Square & Adjusted R Square & Std. Error of the Estimate & Durbin-Watson \\
\hline 1 & $.973^{\mathrm{a}}$ & .948 & .947 & .28745 & 1.032 \\
\hline
\end{tabular}

a. Predictors: (Constant), recognition

b. Dependent Variable: PERFORMANCE OF EMPLOYEE

\begin{tabular}{llrrrrr}
\multicolumn{1}{l}{ ANOVA $^{\mathbf{a}}$} & \multicolumn{1}{c}{ F } & \multicolumn{1}{c}{ Sig. } \\
\hline Model & & Sum of Squares & df & Mean Square & \multicolumn{1}{c}{ F } \\
\hline \multirow{2}{*}{1} & Regression & 118.164 & 1 & 118.164 & 1430.059 & $.000^{\mathrm{b}}$ \\
& Residual & 6.528 & 79 & .083 & & \\
\hline & Total & 124.691 & 80 & & & \\
\hline
\end{tabular}

a. Dependent Variable: PERFORMANCE OF EMPLOYEE

b. Predictors: (Constant), recognition

Interpretation: The $\mathrm{R}^{2}$ value of 0.973 shows a significance positive relationship between employee performance and employee recognition. The Adjusted $\mathrm{R}$ value indicates that $94.8 \%$ variations on employee performance in the non-profit organizations are accounted for by employee recognition. Also, the value off (143.59) and $p$ value $(0.000)$ which are greater than $\mathrm{f}$ critical value at $0.05 \%(6.39)$ and less than alpha $(0.05)$ respectively are positive signs of relationship.Also the DW tests show that the residuals from the linear regression are independent, while there is no first order linear autocorrelation in the simple regression data. Since the values fall between $1.611<\mathrm{d}<1.662$ and they tend to be closer to 4 as against 0 .

Decision: Since F calculated (354.69) is greater than F critical (6.39) and the p value (0.000) is less than alpha (0.05), we therefore reject the Null hypothesis and accept the alternative hypothesis which states that there is positive relationship between employee performance and employee recognition.

\section{Discussion of Findings}

This study was aimed at determining the effect of employee motivational strategies on employee performance. The study found that there is positive relationship between employee performance and motivational strategies. This is in line with the findings of the studies of Richard (2014), Ekpudu and Ojeifo, (2014), Saleem, (2011), Elnaga and Imran (2013), Muindi and K'Obonyo (2015) and Abdullah and Wan (2013).

Also, it was discovered through the study that there is positive relationship between employee performance and financial incentives. This conforms to the findings of Richard (2014), Ekpudu and Ojeifo, (2014) and Saleem, (2011). This signifies that when employees are paid salaries and wages commensurate with their input at work, they tend to perform better than when they notice poor relationship.

It was equally revealed through the study that there is positive relationship between employee training and performance of employees of non-profit organizations. This is in line with the findings of Richard (2014) and Elnaga and Imran (2013) which found significant relationship between the two variables. Thus, when employees are well trained, they perform better in the workplace. 
Moreover, just like the findings of Richard (2014) and Muindi and K'Obonyo (2015), this study revealed that there is positive relationship between employee performance and quality of working life programme. In other word, quality of work life programs should be associated with such affective outcomes such as increased job satisfaction, improved employee performance to the extent that they enhance employee participation, and involvement and responsibility.

It was moreover, found that there is positive relationship between employee performance and employee recognition. This is in tandem with the findings of Richard (2014), Abdullah and Wan (2013), Mikee (2003) and Smith (2005) whose studies disclosed that recognition is important to most volunteers in most non-profit organizations. This is to say that when employees' contribution to the organizations are recognized and appreciated, employees tend to perform better.

\section{Conclusion}

Since it was discovered that adequate compensation positively affect employee performance, with a strong affirmation, it means that non-profit organizations in Nigeria adequately compensate employees and it also shows that employees could work for less pay and still feel motivated to perform their job effectively if they are adequately compensated. Again, a conducive work environment with result to improved health condition, greater job satisfaction, improved cooperation with co-workers, improved productivity, greater commitment, improved concentration and focus, emotional stability, innovativeness, and better customer relation. Finally, employee involvement has improved the psychological make-up of employees, better perception of the goals and objectives of the organization, as well as effective conflict handling.

\section{Recommendations}

Based on the findings of the study, the following recommendations are advanced.

1. Employees should strive to continually improve their capabilities through improvement to enable them cope with the complex and constantly changing work environment.

2. Managers of non-profit organizations should ensure adequate compensation of staff to reduce the rate of employee turnover.

3. Employees of non-profit organizations are advised to have self awareness of their pay structure as this is necessary to facilitate proper adaptation of their compensation which is a motivating factor.

4. Again on the part of managers, they should ensure that employees are involved in organizational decision making. This is because, employees have greater job commitment when they are involved in the decision making process of the organization.

\section{References}

Abdullah, A. A., \& Wan, H. L. (2013). Relationships of non-monetary incentives, job satisfaction and employee job performance. International Review of Management and Business Research, 2(4).

Ahmed, C. P. (2010). Productivity and motivation in response. Industrial and Commercial Training, 33(1), 26-28.

Ajila, P. D., \& Anyanwu, A. A. (2004). Job satisfaction characteristics of higher education faculty by race. African Journal of Business Management, 4(5), 389-300.

Bernet, T. B. (2002). Performance Management Best Practices. New York: McGraw-Hill.

Bower, R. S. (2000). Personnel and Human Resource Management (4 $4^{\text {th }}$ Ed.). Boulevard: West Publishing Company.

Chopra, S. (2002). Handbook of Human Resource Management in Government ( $3^{\text {rd }}$ Ed.). Jocy-Bass: San Francisco.

Daniel, E. M. (2001). Designing an effective performance management system. Journal of Motivation and Management, March/April, 25-29.

Dunmng, L. M. (2001). ResearchMethods in Management ( $6^{\text {th }}$ Ed.). New York: Routledge.

Ekpudu, J. E., \&Ojeifo, S. A (2014). Financial incentives and rewards on employee motivation in the Nigerian Electricity Distribution Company. European Journal of Business and Management, 6(2).

Elnag, L. D., \& Imran, P. T. (2013). The Effect of Training on Employee Performance. European Journal of Business and Management, 5(4)

Herzberg, F. (1984). The Motivation to Work. New York: John Willey and Sons Inc.

Higgins, R. (1994). Incentives of organizations. Journal of Economics Perspectives, (4), 115-132. 
John, P. D. (1976). Historical Perspectives on Non-Profit Organizations in the United States, in Herman, R. (Ed.). The Job-Base Handbook of Non-Profit Management and Leadership. San Francisco: Jossey-Bass Publishers.

Koontz, E., \& Weihrich, A. (1990). Motivation and Effectiveness: A Psychological Approach.New York: McGraw Hill.

McClelland, D. C., \& Burnham, D. H. (1987). Essential Theories of Motivation and Leadership. New York: M. E. Sharpe Inc.

Mullins, L. J. (2005). Management and Organizational Behaviour ( $7^{\text {th }}$ Ed.). New Delhi.: Prentice Hall.

Olusegun, R. I., \& Ayo, S. J. (2009). Practical Guide to Performance Appraisal. Personnel Journal, May, 72-77.

Probst, O. C., \& Brubaker, P. (2011). The Provision of Incentives in Firms. Journal of Management Literature, 13, 31-33.

Richard, B. (2014). The Effect of Motivation on Employees' Performance: Empirical Evidence From the Brong Ahafo Education Directorate. A unpublishedThesis, Department of Managerial Science, Kwame Nkrumah University of Science and Technology.

Saleem, S. (2011). The Impact of Financial Incentives on Employees Commitment. European Journal of Business and Management, 3(4).

Simel, G. (1994). Human Resource Management (4 $4^{\text {th }}$ ed.). New Delhi: McGraw-Hill.

Sirgrist, R. S. (1996). Personnel and Human Resource Management (4 ${ }^{\text {th }}$ ed.). Boulevard: West Publishing Company.

\section{Copyrights}

Copyright for this article is retained by the author(s), with first publication rights granted to the journal.

This is an open-access article distributed under the terms and conditions of the Creative Commons Attribution license (http://creativecommons.org/licenses/by/4.0/). 